\title{
Decay Resistance of Weathered Beech Wood
}

\author{
Şebnem Sevil ARPACI* Merve CAMBAZOĞLU Eylem DİZMAN TOMAK \\ Bursa Technical University, Faculty of Forest, Forest Industry Engineering Department, 16310, Bursa, Turkey
}

How to cite: Arpacı, Ş.S., Cambazoğlu, M. \& Dizman Tomak, E. (2020). Decay Resistance of Weathered Beech Wood. J. Anatolian Env. and Anim. Sciences, 5(5), 882-885.

Atıf yapmak için: Arpacı, Ş.S., Cambazoğlu, M. \& Dizman Tomak, E. (2020). Yaşlandırılmış Kayın Odununun Mantar Çürüklük Dayanımı. Anadolu Çev. ve Hay. Dergisi, 5(5), 882-885.

(iD): https://orcid.org/0000-0002-2591-2837

(iD) : https://orcid.org/0000-0001-8001-686X

(iD): https://orcid.org/0000-0001-8654-0005
Abstract: Wood is susceptible to photo-degradation in outdoor applications, and deformations occur on its surface such as micro or macro cracks, color changes etc. Especially, cracks make wood material more vulnerable to biotic attacks. In this study, decay resistance of natural and accelerated weathered beech samples was investigated by a brown (Coniophora puteana) and white rot (Coriolus versicolor) fungi attacks. For this purpose, beech samples exposed to natural weathering (NW) for 393 days, and accelerated weathering (AW) for $1512 \mathrm{~h}$, and then subjected to decay test in malt extract agar medium for 2 and 4 weeks. After 2 weeks of decay testing, weight loss of samples by $C$. versicolor was found to be $24.30 \%$ for controls, $13.29 \%$ for AW samples and $24.38 \%$ for NW samples. In the case of C. puteana, it was found as $21.15 \%, 21.49 \%$ and $30.61 \%$ for controls, AW samples and NW samples, respectively. Weight loss of samples by C. versicolor was found to be $61.82 \%$ for controls, $30.72 \%$ for AW samples and $37.62 \%$ for NW samples, after 4 weeks of decay testing. The weight loss by 4 weeks exposure of $C$. puteana was found to be $21.43 \%, 28.44 \%$ and $37.67 \%$ for controls, AW samples and NW samples, respectively. Natural weathering caused more weight loss than accelerated weathering test for both fungi species.

Keywords: White rot, brown rot, natural weathering, accelerating weathering, beech.

\section{Yaşlandırılmış Kayın Odununun Mantar Çürüklük Dayanımı}

*Sorumlu yazarın:

Şebnem Sevil ARPACI

Bursa Teknik Üniversitesi, Orman Fakültesi, Orman Endüstri Mühendisliği Bölümü, 16310, Bursa, Türkiye.

$\triangle$ : sebnem.arpaci@btu.edu.tr

Cep telefonu : +90 (541) 5902360

Telefon : : $+90(224) 3003857$

Faks $\quad:+90(224) 3003429$
Öz: Ahşap dış mekan uygulamalarında foto-degradasyona karşı hassas bir malzeme olup, yüzeyinde mikro veya makro çatlaklar ile renk değişiklikleri gibi deformasyonlar meydana gelmektedir. Özellikle çatlaklar, ahşap malzemeyi biyotik saldırılara karşı daha savunmasız hale getirmektedir. $\mathrm{Bu}$ çalışmada, doğal ve hızlandırılmış yaşlandırma testi uygulanmış kayın örneklerinin esmer (Coniophora puteana) ve beyaz çürüklük (Coriolus versicolor) mantar saldırılarına karşı dayanımı araştırılmıştır. Bu amaçla, 393 gün boyunca doğal dış ortam testi (NW) ve 1512 saat süreyle hızlandırılmış yaşlandırma testine (AW) maruz kalan kayın örnekleri, 2 ve 4 hafta boyunca malt ekstrakt agar ortamında çürüklük testine tabi tutulmuştur. 2 hafta boyunca $C$. versicolor mantarının saldırısına bırakılan örneklerin ağırlık kaybı kontroller için $\% 24,30$, AW örnekleri için \%13,29 ve NW örnekleri için \%24,38 olarak bulunmuștur. $C$. puteana' ya maruz bırakılan kontrol, AW örnekleri ve NW örnekleri için ise ağırlık kaybı sırasıyla $\% 21,15, \% 21,49$ ve $\% 30,61$ olarak bulunmuștur. 4 hafta boyunca $C$. versicolor'a maruz birakılan örneklerin ağırlık kaybı kontroller için \%61,82, AW örnekleri için \%30,72 ve NW örnekleri için $\% 37,62$ olarak bulunmuştur. C. puteana' ya 4 hafta boyunca maruz bırakılan örneklerin ağırlık kaybı kontroller, AW örnekleri ve NW örnekleri için sırasıyla \%21,43, \%28,44 ve \%37,67 olarak bulunmuştur. Doğal dış ortam testi, her iki mantar türü için hızlandırılmış yaşlandırma testinden daha fazla ağırlık kaybına neden olmuştur.

Anahtar kelimeler: Beyaz çürüklük, esmer çürüklük, doğal dıș ortam testi, hızlandırılmıș yașlandırma testi, kayin. 


\section{INTRODUCTION}

During outdoor exposure, wood may undergo serious changes of its physical and structural properties due to the combined effect of sunlight (UV), oxygen, moisture, atmospheric pollutants and microorganisms. The combination of oxygen and UV rapidly causes the oxidation of lignin and hemicellulose, and depolymerization of cellulose. Most of the reaction products are water soluble, so they are easily removed from the wood surface by rain, resulting in weight loss, roughness and color changes (Xie et al., 2005; George et al., 2005; Evans, 2008; Lionetto et al., 2012). Weathering studies of wood can be both performed in laboratory and real outdoor conditions. Laboratory weathering test also known as artificial weathering test includes ultraviolet light and moisture cycles, and this procedure is generally accepted as a simulation of outdoor conditions. However, in reality there are many other degradation factors in outdoor such as colonization of microorganisms, aerosols, mechanical effects of wind, human, etc. Therefore, both experiments in laboratories and outdoor exposure tests in ground and above ground situations are essential for service life assessment of wood (Brischke and MeyerVeltrup, 2015; Metsa-Kortelainen and Viitanen, 2017; Tomak et al., 2018).

In outdoors, wood undergoes biological decay by white, brown and soft rot fungi. Basidiomycetes are responsible for the most of wood decay in constructions (Bari et al., 2015). During exposure to fungal attack, significant changes occur in wood chemical composition, resulting in significant weight loss, mechanical strength loss and aesthetical defects. Weathering tests prior to decay tests can accelerate wood degradations, and can help the simulating of outdoor degradations in shorter time. The combination of the weathering tests and decay tests may become a new strategy to test wood preservatives in future. Studies on decay test of wood and/or wood-based composites after weathering tests showed that weathering affected decay process. Catto et al. (2016) investigated the effect of natural weathering and decay test by Trametes villosa, Trametes versicolor, Pycnoporus sanguineus and Fuscoporia ferrea. The results showed that natural weathering accelerated fungal degradation by influencing fungal growth. Decay resistance of weathered albizzia and sugi wood samples was studied by Sudiyanni et al. (1996). They found that weathered samples had higher weight loss than control samples. In another study, oak wood was naturally and artificially aged, and then, were inoculated with brown and white rot fungi. In that study, brown-rot fungi caused greater change in weight-loss in naturally aged samples than white-rot fungi did (Chow and Bajwa, 1998). Reinprecht and Grznárik (2015) reported that the artificial ageing decreased the decay resistance of the modified or the modified and painted pine sapwood. Decay test of weathered beech samples showed that samples had darker color than that of controls due to the weight loss after $C$. puteana attack (Reinprecht and Hulla, 2015).

In this study, decay resistance of natural and accelerated weathered beech samples was investigated by a brown (Coniophora puteana) and white rot (Coriolus versicolor) fungi. Samples were exposed to natural weathering (NW) for 393 days, and accelerated weathering (AW) for $1512 \mathrm{~h}$, and then were subjected to decay test in malt extract agar medium for 2 and 4 weeks. Weight loss of samples was compared with un-weathered samples (controls).

\section{MATERIALS AND METHODS}

Materials: Beech samples were obtained from Sulekler Forest Industry, Bursa, Turkey. The samples were produced industrially. Samples with dimensions of $2 \mathrm{~mm}$ (radial) $\times 75 \mathrm{~mm}$ (tangential) x $150 \mathrm{~mm}$ (longitudinal) were prepared for artificial and natural weathering tests. After weathering tests, the samples were cut into $2 \mathrm{~mm}$ (radial) $\times 5 \mathrm{~mm}$ (tangential) $\times 30 \mathrm{~mm}$ (longitudinal) for the decay test. Samples without any visible defects such as cracks, strain and knots were selected prior the experiments, and then oven-dried. Malt extract agar sourced from Merck (Darmstadt, Germany).

\section{Method}

Artificial weathering: Artificial weathering was carried out in the Atlas UV Test machine (Illinois, USA) according to ASTM G154 (2016) standard. The weathering cycle consisting of a continuous UV $\left(340 \mathrm{~nm}, 0.89 \mathrm{~W} / \mathrm{m}^{2}\right)$ for $8 \mathrm{~h}$ at $60^{\circ} \mathrm{C}$ followed by a condensation for $4 \mathrm{~h}$ at $50^{\circ} \mathrm{C}$ was applied for $1512 \mathrm{~h}$.

Natural weathering: Samples were exposed to outdoor conditions in south at an angle of $45^{\circ}$ to the horizontal in Bursa Technical University campus with an altitude of $162 \mathrm{~m}$ in Bursa, Turkey for the period from November 2018 to November 2019 according to principles of ASTM G7 (2013) and EN 927-3 (2003) standards.

Decay test: The decay test was performed according to EN 113 (1997) principles, with some changes in sample size and kolle flasks. 6 replicates were used for each group. Malt extract agar solution of $4.8 \%$ concentration, and the samples were sterilized in an autoclave (Tomy SX700, Japan) at a pressure of about 0.1 $\mathrm{MPa}$ at $120^{\circ} \mathrm{C}$ for $25 \mathrm{~min}$. Fungi cultures of the brown rot fungus Coniophora puteana (Schumach.) P. Karst. (Mad515) and white rot fungus, Coriolus versicolor (Linnaeus) Quelet (1030) were inoculated to sterile malt extract agar medium in the petri dishes. Samples were incubated at $20^{\circ} \mathrm{C}$ and $70 \% \mathrm{RH}$ for 2 and 4 weeks. After the test, oven 
dry weights of samples were determined. The weight loss was calculated by the following equation:

Weight loss $(\%)=($ Mint-Mend $/$ Mint $) \times 100$

Where,

$\mathrm{M}$ is the weight of the samples and the subscripts "int" and "end" refer to the oven-dry weight at $103^{\circ} \mathrm{C}$ before and after the decay test, respectively.

\section{RESULTS AND DISCUSSION}

The weight loss of the samples is illustrated in Fig. 1 for $C$. versicolor, and Fig. 2 for $C$. puteana attack. The weight loss of control samples showed that the decay test was valid, and the test conditions were suitable for growth of the fungi. Test fungi showed suitable growth and colonization of the mycelium on all samples.

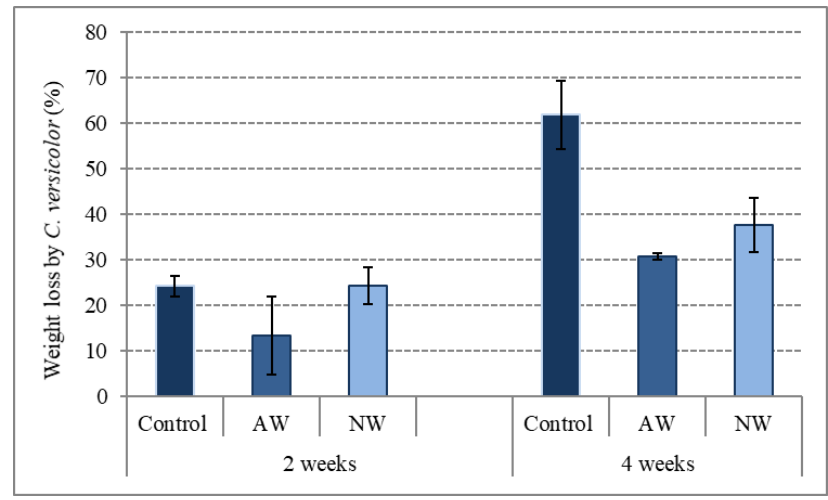

Figure 1. Weight loss of samples caused by C. versicolor attack.

After 2 weeks, natural weathering and control samples degraded almost similarly around $24 \%$ by $C$. versicolor attack. Fungal degradation was found to be less in the artificial weathering samples $(13.29 \%)$ than in the others. This may be explained by the rapid degradation of the chemical components of wood (especially lignin) due to artificial degradation. Samples thickness was around $2 \mathrm{~mm}$, and this could accelerate the photo-degradation. At the end of the 4 weeks, the weight loss of beech samples was $61.82,30.72$ and $37.62 \%$ for control, artificial weathering and natural weathering samples, respectively (Figure 1). Panek et al. (2014) stated that artificial weathered beech samples exhibited less weight loss than the untreated control samples.

Artificial weathering and control samples degraded almost similarly after 2 weeks of $C$. puteana exposure. At the end of the 4 weeks, the weight loss of beech samples was 21.43, 28.44 and $37.67 \%$ for control, artificial weathering and natural weathering samples, respectively. Natural weathering samples degraded more than artificial weathering samples for both decay fungi. Cracks and voids in the natural weathered samples could cause an entrance for fungi mycelium, and cause an increase in the moisture uptake during the decay test, and therefore may create more suitable conditions for fungal growth. Furthermore, different degradation rates of wood components between the weathering methods could also have an important role on the weight losses by fungi attacks.

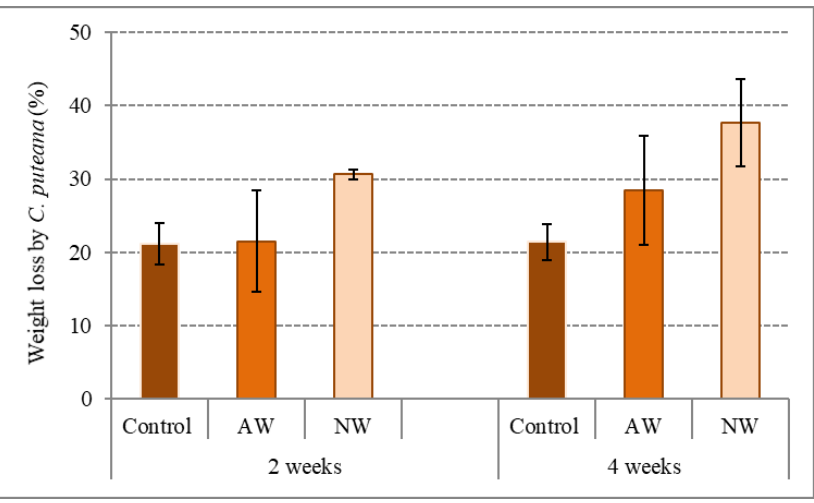

Figure 2. Weight loss of samples caused by C. puteana attack.

In Fig. 1, control samples showed higher weight loss than weathered samples however in Fig. 2, weathered samples had higher weight loss than controls. The decay mechanism of $C$. versicolor and $C$. puteana might be the main reason for this finding. Brown rotter's primarily attack the cell-wall carbohydrates, leaving a modified lignin at the end of the decay process. Simultaneous whiterotter's attack all cell-wall constituents (Zabel and Morell, 1992). Weathering also causes a decrease in lignin component. In fact, weathering is a surface phenomenon. But in this study the thickness of the samples is quite small, and therefore the degradation could be deeper inside the sample. It may be concluded that the chemical components in the control samples are higher than the weathering samples, and thus may create a more suitable medium for $C$. versicolor growth than weathered samples. In the decay process of $C$. puteana, wood carbohydrates were degraded, and lignin was previously degraded in weathered samples. However, only carbohydrate degradations occurred during C. puteana attack in controls. This could cause a less weight loss in controls than weathered samples after $C$. puteana attack.

\section{CONCLUSION}

This study aimed to investigate the decay resistance of natural and accelerated weathered beech samples against $C$. puteana and $C$. versicolor attacks. The results showed that fungi species and weathering methods affected the decay resistance of samples. Natural weathering samples degraded more than artificial weathering samples after both decay fungi exposure. Different degradation rates of wood components between 
the weathering methods probably played an important role on the weight losses by fungi attacks. Control samples showed higher weight loss than weathered samples after $C$. versicolor exposure, however, they had lower weight loss than weathered samples after $C$. puteana exposure probably related with the decay mechanism of white and brown rot fungi. 4 weeks of exposure to $C$. versicolor caused more weight loss than $C$. puteana for all samples since white rots in hardwoods are generally more severe. More studies are needed for better understanding in decay mechanism of weathered wood.

\section{ACKNOWLEDGMENTS}

The authors are grateful to Sulekler Forest Industry, Bursa, Turkey for supplying the free-sample of woods materials. Weathering tests of this study was financially supported by Turkish Scientific and Research Council (TUBITAK) under the project number of 1180759. This study was oral-presented in ORENKO 2020 held by Karadeniz Technical University, Trabzon..

\section{REFERENCES}

ASTM G154. (2006). Standard Practice for Operating Fluorescent Light Apparatus for UV Exposure of NonmetallicMaterials. American Society for Testing and Materials.

ASTM G7. (2013). Standard Practice for Atmospheric Environmental Exposure Testing of Nonmetallic Materials.

Bari, E., Nazarnezhad, N., Kazemi, S. M., Ghanbary, M. A. T., Mohebby, B., Schmidt, O. \& Clausen, C. A. (2015). Comparison between degradation capabilities of the white rot fungi Pleurotus ostreatus and Trametes versicolor in beech wood. International Biodeterioration \& Biodegradation, 104, 231-237.

Brischke, C. \& Meyer-Veltrup, L. (2015). Moisture content and decay of differently sized wooden components during 5 years of outdoor exposure. European Journal of Wood and Wood Products, 73(6), 719-728.

Catto, A.L., Montagna, L.S., Almeida, S.H., Silveira, R. M. \& Santana, R.M. (2016). Wood plastic composites weathering: Effects of compatibilization on biodegradation in soil and fungal decay. International Biodeterioration \& Biodegradation, 109, 11-22.

Chow, P., \& Bajwa, D. S. (1998). Weathering effects on the decay resistance of creosote-treated oak. In V: Ninety-fourth annual meeting of the American Wood-preservers' Association. Scottsdale, Arizona Vol. 94.
EN 113. (1997). Wood preservatives. Test method for determining the protective effectiveness against wood-destroying basidiomycetes. Determination of toxic values.

EN 927-3. (2003). Paints and varnishes - Coating materials and coating systems for exterior wood-Part 3: Natural weathering test.

Evans, P.D. (2008). Weathering and photo-degradation of wood. In: Development of Wood Preservative Systems, ACS Washington DC, USA: 69-117pp.

George, B., Suttie, E., Merlin, A. \& Deglise, X. (2005). Photodegradation and photostabilisation of wood: The state of the art. Polym. Degrad. Stab., 88, 268274.

Lionetto, F., Del Sole, R., Cannoletta, D., Vasapollo, G. \& Maffezzoli, A. (2012). Monitoring wood degradation during weathering by cellulose crystallinity. Materials, 5(10), 1910-1922.

Metsa-Kortelainen, S. \& Viitanen, H. (2017). Durability of thermally modified sapwood and heartwood of Scots pine and Norway spruce in the modified double layer test. Wood Material Science \& Engineering, 12(3), 129-139.

Panek, M., Reinprecht, L. \& Hulla, M. (2014). Ten essential oils for beech wood protection-Efficacy against wood-destroying fungi and moulds, and effect on wood discoloration. BioResources, 9(3), 55885603.

Reinprecht, L. \& Grznárik, T. (2015). Biological durability of Scots pine (Pinus sylvestris L.) sapwood modified with selected organo-silanes. Wood Research, 60(5), 687-696.

Reinprecht, L. \& Hulla, M. (2015). Colour changes of beech wood modified with essential oils due to fungal and ageing-fungal attacks with Coniophora puteana. Drewno: prace naukowe, doniesienia, komunikaty, 58.

Sudiyanni, Y., Imamura, Y. \& Takahashi, M. (1996). Weathering effects on several properties of chemically modified wood. Wood Research Institute Kyoto University, 83, 55-58.

Tomak, E.D., Ustaomer, D., Ermeydan, M.A. \& Yildiz, S. (2018). An investigation of surface properties of thermally modified wood during natural weathering for 48 months. Measurement, 127, 187-197.

Xie, Y., Krause, A., Mai, C., Militz, H., Richter, K., Urban, K. \& Evans, P.D. (2005). Weathering of wood modified with the N-methylol compound 1,3dimethylol-4,5-dihydroxyethyleneurea. Polym. Degrad. Stab., 89, 189-199.

Zabel, R.A. \& Morrell, J.J. (1992). Wood microbiology decay and its prevention. Academic Press, London. 